\title{
THE INTERNATIONAL INVESTMENT AGREEMENT NOWADAYS: FROM THE CONSENT TO ITS SOCIAL FUNCTION AS A GUARANTOR OF THE INTERESTS OF CITIZENS ${ }^{1}$
}

Renata Alvares Gaspar

Full-time research professor at the Law School of PUCCampinas. PhD in Law and Master in Latin American Studies from the University of Salamanca. Leader of the Research Group Law in a Globalized World. ASADIP Vice President of Communications and Publications: American Association of Teachers of International Law.

Felipe Soares Vivas de Castro

Tutored for Scientific Initiation by the co-author. Bachelor student at PUC Campinas Law School. He developed this research with the CNPq scholarship.

Received: 2017-10-30. Accepted:2017-12-02

\begin{abstract}
At the center of a globalized world and under intense transnational financial circulation, there is the foreign investment. In this sense, investigating the realization of the social and economic functions of the Foreign Investment Agreement is an insurmountable necessity for understanding its effects on the citizenship rights. Therefore, it was discussed the rapid and multiple transformations that the International Investment Law has been supporting over time and the direct reflection on the formation of the Foreign Investment Contracts that, nowadays, require complex answers to the achievement of legal security.
\end{abstract}

Keywords: International investment agreement - Economical function. Social function - Development - Citizenship.

1 Translated by Paula de Oliveira Henriques 


\section{INTRODUCTION}

In the contemporary world, the deeply globalized world presents the intense transnational financial flow, also, as an opportunity for the development of societies around the globe. However, the circulation of capital per se is not favorable to the people - almost all of the time. This is because the international financial flow is fundamental to the development of economically vulnerable societies in the current economic-productive model, but is only able to achieve this when there is effective citizen control over the circulation of capital.

From this, it is possible to infer that capitalism essentially needs constant commercial expansion for its existence based on maximizing profitability and accumulation, and on the other hand, civil society can, through the equipping of global governance bodies, enhance its control over the international financial flow in defense of its developmental interests. Thus, in order to better understand the conflicting relation between invested capital and the concrete development of receiving states, the international investment contract exits as a natural object of scientific approach, as it is a mandatory legal instrument in investment relations between sovereign States and foreign investors.

In this section, an attempt is made to understand the international investment agreement at the present time through the hermeneutical approach of its social and economic functions. It is clear that the international agreement, particularly that of investment, has undergone numerous transformations since its inception - after all, it is representative of extremely conflicting, complex and stressed from global political and economic transformations cross-border relations, and therefore requires thorough understanding. Thus, it is possible to see the shift in the genesis of the international ageement, which legal security was modernly based on the traditional civilist conceptions of reciprocal obligations and which, at the same time, finds legal stability that is fundamental to it, precisely, in the legitimacy granted only by citizen participation in the business of the sovereign states to legal transactions involving foreign capital. For no other reason, it is necessary to investigate whether, in fact, the international investment agreement provides spaces of struggle - always considering the emancipatory potential of the Law to Citizenship in order to allow the attainment of development as a fundamental human right.

In this sense is that a scientific incursion is made on the investment contract at the present time, delimiting its training center, its economic and social effects, as well as its reflections on citizenship 


\section{THE INTERNATIONAL INVESTMENT CONTRACT: FROM THE CLASSIC TO THE CONTEMPORARY}

Undoubtedly, the practical issues related to foreign investment ${ }^{2}$ are quite complex, as they require the application of law in relations that necessarily involve different legal systems. It is not forgotten, moreover, that, since the Second World War, the world, through the deepening of globalization ${ }^{3}$, has in fact experienced a new economy in which business has been internationalized, companies have extrapolated national borders and countries from the periphery of the epicenter of global capitalist make constant and significant efforts to access global trade as exporters. It is in this context that States and companies have been forced into international cooperation.

In the search for providing security for international trade, the international contract emerged $\mathrm{d}^{4}$ as an "engine of international trade", conferring "juridicity on the economic operations that underlie it", allowing "the formalization of the promises made between the parties, reducing the uncertainties, the risks and costs of the business "(JÚNIOR, 2006, p. 2). The international contract is, therefore, in globalized relations, the legal guarantee that the rights deriving from the established pacts can be fully exercised by the parties involved in economic business of the most varied, including those of foreign investment. Nevertheless, as inherent in Law, the search for legal certainty - embodied in predictability and certainty - is what defines and orders the relationships and decisions of economic agents in the global Market (TRINDADE, 2007, p. 12-31).

In this sense, it must be said that the concept of foreign investment, such as International Investment Law itself, is subject to transformations, over time, due to the pressure exerted by global economic relations in particular; and that the international investment

\footnotetext{
2 In most of the international agreements signed in the field of investment, despite the very broad definitions, foreign investment refers to all types of assets - in a non-exhaustive role that include direct and indirect investments. For UNCTAD, the difference between one and the other lies in the degree of control in the management of investment in another economy that direct investment implies. (JUNIOR, 2014, pp. 13-43).

3 It should be noted that globalization is understood in this work as a complex and unfinished phenomenon, translated by the "intensification of transnational interactions, be they interstate practices, global capitalist practices or transnational social and cultural practices" (SANTOS, 2002, p. .).

4 Only from the nineteenth century can one speak of ... foreign investments" because, in the previous period, investments took place in "colonial territories" and "were subject to metropolitan legal regimes, export of assets "(COSTA, 2012, page 28).
} 
agreement is, at the present time, significantly more complex than the classically known.

Regarding foreign investment, it is well known that the scope of the protection promoted by Investment Law has been greatly expanded since the nineteenth century. While, at the time, foreign investment was heavily used in the development of public infrastructure and the exploitation of natural resources, since the Second World War - for the reasons previously mentioned - there was a deep diversification of foreign investment that, in addition to the traditional loans, started to finance the implementation of industries and service providers.

Moreover, in view of its primary role - as indicated above -, the international investment agreement was classically constructed with the objective of legal protection of the foreign investor, as well as of the investment made, without much concern for the guarantees of the host State. This contractual conception is embodied in the ideal that national state law confers a higher level of protection to the receiving State than to the foreign investor.

\footnotetext{
"Highly vulnerable to interference by the host State, whether through nationalization or expropriation measures, or through restrictions on the repatriation of investor profits, tax increases or other legislative changes" (VICENTE apud BAPTISTA; RIBEIRO, 2014, p. 816).
}

Under this assertion, the investor - vis-à-vis the host States - would be quite vulnerable in international transactions, remaining unprotected and susceptible to sovereignty.

Therefore, it was materialized the international investment agreement, aiming at protecting the resources invested against confiscation and expropriation. In addition, legal engineering has always worked to internationalize economic stability in the execution of foreign investment contracts, protecting the purpose pursued by investors: the profitability of the invested capital.

However, it is true that reality is capable of demonstrating that the aforementioned asymmetry between investor and host state has in fact been oversized in the interests of globalized capital. After all, although undoubtedly foreign investment may to some degree slip in the politicalinstitutional power of the states, it is notorious that countries today are vulnerable to the various economic pressures of the global financial market. ${ }^{5}$. Developing nations, under impoverishment penalties, are

5 In this sense, "at the same time, the relevance of the figure of the state is actually diminished and settled is that these are not the only subjects of international law" (VASCONCELOS, 2016, p. 61). Sobre o tema: VASCONCELOS, Raphael Carvalho de. Teoria do Estado e a Unidade 
embedded in a complex network of international investments, attentive to market patterns, otherwise they will not participate in the international community that is so essential, in the current economic-political model, to the survival of States (CASTRO, 2014, p. 102). As evidence of this, very commonly, investment agreements stablish, through its clauses, "access to a dispute settlement system outside the framework of the host State" (CASTRO, 2014, p. 108), forcing the countries that are recipients of foreign investment to fully subscribe to the economy of the agreements, to risk jeopardizing their credibility with the global market - which would difficult new and essential investments.

The investment agreement, from its classic conception to the most contemporary one, is an indispensable tool to reduce the uncertainties involved in international transactions - improving long-term contracts, as well as the circulation of capital -, protecting investments.

However, the distinguishing note of the contemporary foreign investment agreement is precisely the focus on the current institutional environment, especially the political and social domains that conclude the contract. The fact is that security so persecuted by investors is not only economic - based on predictability of risk - but also legal. With the deep internationalization of contemporary societies, investment contracts have touched upon the most diverse spheres of social interest (HURREL, 2007: 222), thus revealing that investing in disregard for the interests of cosmopolitan citizenship is extremely unsafe.

For all of this, the risks inherent in any foreign investment agreement can be efficiently mitigated by reducing the unpredictability and incompleteness of such instruments. Therefore they must, inexorably, be built with due legal care not only respecting their economic function but, above all, their social function.

\section{LEGAL SECURITY AND ECONOMIC FUNCTION.}

In fact, it can not be denied that the obsession with international investment agreement is consonant with that of international law: to create and consolidate international regulatory systems "capable of enhancing international legal certainty", facilitating, by reducing political risks and costs international economic flows (COSTA, 2006, p.60). Such international regulation is expressive in the field of economic relations and is based on the protection and promotion of investment, usually through complex international regulatory systems which, although not specifically intended for foreign investment (such as the World Bank, the IMF and the WTO, for example ) are technical or dispute settlement bodies designed to impose limits on the sovereignty

do Direito Internacional. Belo Horizonte: Arraes, 2016. 
of States in the economic execution of investment contracts.

Obviously, the classical conformation of the foreign investment agreement is not accidental, but, on the contrary, it assumes the guarantee of the economic effects expected by the investor on the aforementioned pact. In this sense, it is appropriate to affirm that the primary function of the investment agreement is to provide economically, with legal certainty, the underlying business with the receiving State.

For this reason, it should not be forgotten that investments are regulated, with a protective purpose, by international contracts that is, by the Law of Investments -, however, they are economic in nature, related to the capital flow that inserts them in the process of maintenance of the capitalist system itself, based on constant expansion of currencies. Under this economic dimension, foreign investment takes place in the perspective of the resulting profit - confirming, in fact, the relevance of the economic function of the international investment agreement for the construction of legal instruments that are safe for the investor. In this sense, moreover, the Model Bilateral Investment Treaty elaborated by the United States pointed as a characteristic of international investments "the commitment of capital or other resources" related to the "expectation of gain or profit".

Undoubtedly, the relative ${ }^{6}$ legal certainty established by the investment agreement, in view of its economic function, was, moreover, capable of overcoming the traditional barriers of international trade, favoring the internationalization of mass production, commercialization and financing of goods and services. The referred agreement allows the realization of foreign investment even in the face of the investor's fear of being involved in the complex litigation in which the receiving State is the contracting party and at the same time, regulatory authority ${ }^{7}$. For this reason, the investment agreement subjects the parties to very strict rules, especially, favoring the autonomy of the will.

Moreover, that since the nineteenth century, economic liberalism

6 There is a great demand for international investment regulations in order to make international contracts more flexible in order to increase legal certainty for investors, for example unilateral disruptions promoted by recipient states. In the same way, throughout the twentieth century, the construction of "an effective system of global order and law that allows international business to provide trustworthy legal instruments" (RIBEIRO, 2014, 128) has been demanded.

7 Here, it is necessary to consider, in addition to the Judiciary, the Legislative Branch, which can undoubtedly create legal norms that, because they are contrary to the interests of the foreign investor, may adversely affect the profitability of the investment made. For example, public policies for tobacco control that go head-on against the goals of the transnational tobacco industry. To know more about it, it is recommended: VEDOVATO, Luís Renato; VEDOVATO, Tatiana Giovanelli; SPERANDIO, Ana Maria Girotti. The role of international law in domestic legislation on tobacco control. Journal of Health Law. São Paulo, n. 3, v. 13, p. 150-175, Nov./ fev. 2013. 
has been establishing an environment favorable to the acceptance on a global scale of the principle of autonomy of the will for the benefit of the economic order; that is, the argument is based on the economic efficiency of investment agreements.

For an adequate understanding of the economic function, founding of investment agreements, it is necessary to remember that the contracts are legal instruments that have gained the current contours from the economic theories of the eighteenth century that, by a series of historical ${ }^{8}$ factors, defended freedom ${ }^{9}$ as a universal panacea and the free movement of wealth as a social necessity. In this sense, the contract was traditionally constructed as an instrument of defense of freedom with a view to the movement of goods and that would carry, in a self-absorbed way, the belief of a natural equity capable of performing justice between the parties - quid it contractuelle, dit juste (MARQUES, 2014, p. 67).

Furthermore, it should be noted that the autonomy of the will is explained, precisely, by the theoretical construction carried out around the investment agreements so that its economic function executes the legal protection. The classical doctrine on the subject argues that, although not unlimited, the will of the parties - in international contracting - is widely accepted (STRENGER, 1998, p. 117) and should be able, most of the times, to prevent the interference of the national judiciary in the manifest will in the instrument contracted between the receiving State and the foreign investor (ARAUJO, 2000, pp. 11-18).

Uncontroversially, autonomy of the will is a delicated issue for all parties involved in foreign investment transactions. After all, it is the space for the State to attempt to impose its sovereignty on contracting and, on the other hand, the foreign investor seeks to subject the contract to conditions that are less favorable to state intervention (DOLZER, Rudolf, Christoph, 2008, p. 80-82) - on the grounds that contractual balance must be achieved, since there would be a potential political risk in contracting involving sovereign States. In this context, it must be remembered, however, that the host States, in their participation in international business, contractually limit their sovereignty to guarantee the flow of investments without which they could not subsist in a globalized world.

In the practice of international contracting what is sought, finally, is the contractual security capable of guaranteeing the immutability of clauses with economic content, protecting the investment in order to allow the complete realization of its cycle, from the investment to the remuneration of contributed capital.

8 These economic theories arose as a response to corporatism and to the limitations imposed on bourgeois practices by the Catholic Church.

9 Here, it refers to the freedom that seeks to realize the individual interests of those who contract 
Therefore, the legal framework perfected over time to support the ideal of the need to protect investment against the power of host States has remained consolidated in the foreign investment contract, built with privilege to the autonomy of the will, in order to grant legal certainty to the economic objective of foreign investors.

The contemporary contours, however, as will be seen below, challenge the legal security afforded by international investment agreement that are built exclusively with respect to their economic function.

\section{THE ACTUALITY OF THE INVESTMENT CONTRACT AND ITS SOCIAL FUNCTION}

The legal security, that is so essential to foreign investment, as already discussed in this paper, has been pursued through the economic function of international investment agreements. However, investment agreements - as complex as they may be - The legal security so essential to foreign investment, as already discussed in this paper, has been pursued through the economic function of international investment contracts. However, investment agreements - however complex they may be - have been challenged, first by the lack of definition of what the autonomy of the will is in each legal system and, second, by the globalization of trade and the development of a multicultural society that demands protection of the individual and his dignity and cultural identity (ROSADO, 2016, p. 359).

In view of the object of this research, however, it is only necessary to state - in addition to the discussion of the previous topic - that the meaning of private autonomy, intrinsically related to the economic function of the contracts, does not find correspondence in the diverse legal traditions existing around the globe and, on the contrary, it does not seem to move to a common denomination ${ }^{10}$. Thus, one suddenly sees the inability of the autonomy of the will, by itself, to guarantee robust legal security to international business:

y esto nada tiene de sorprendente, la diversidad de los significados posibles de este concepto - tan caro al derecho contractual de tradición occidental, pero tan extraño al de las demás tradiciones jurídicas no es sino la expresión, en este dominio específico,

10 To understand in detail and depth the different meanings of the concept of private autonomy in contemporary legal families in the light of Comparative Law, it is recommended to read: VICENTE, Dário Moura. La autonomía privada y sus distintos significados a la luz del derecho comparado. In: ARROYO, Diego P. Fernandez; RODRÍGUEZ, José Antonio Moreno. (Org.). Contratos internacionales. Buenos Aires: ASADIP, 2016. 
de la inmensa diversidad de los derechos a través de las fronteras. Esta diversidad es, a su vez, una consecuencia inevitable de la naturaleza cultural del derecho (...) y de la intrínseca variabilidad de todas las manifestaciones de cultura humana (VICENTE, 2016, p. 81-82).

It is to be recognized that, in today's pluralistic and fragmented world, protection of the rights of the people - in the context of foreign investment - demands far more sophisticated solutions than classically constructed formalists and conformists. If the investment agreement represents the legal security that is so necessary for international investment, it can not ignore the current scenario in which the financial market is inserted, always having to be attentive to the aspirations of the Citizenship - the ultimate recipient of the resources invested. For this, the international investment agreement must also be built with attention to its social function. The social function of the investment contract is certainly justified by the sociological bias, especially by the ideal of sociality ${ }^{11}$, but also by its economic importance, since, as pointed out, it is indispensable to the effective security of investments in postmodernity ${ }^{12}$.

Unsurpassed in the broad understanding of the social function of the contract is also to observe its historical construction that occurred from the idea of limitation to the exercise of property rights.

Since St. Thomas Aquinas, the ideal about the existence of a social function, besides the economic one, has been theorized although not under such denomination. The aforementioned Catholic philosopher, when questioning the legitimacy of someone possessing a property exclusively ("whether it is lawful for a man to possess a thing as his own?"), defended the ideal that all goods, although appropriated individually, have a common destiny that must be observed ${ }^{13}$ (AQUINO,

11 It is the social duty of common responsibility that authorizes the relativization of subjective rights with the use of the principle of social function in private relations (RAISER, Ludwig apud GEHLEN, 2004, p.179).

12 Postmodernity is strongly marked by the crisis of mistrust in law, its instruments and institutions (including the contract), which favors the increase of litigation, with direct effects on private law (MARQUES, 2014, p.185).

13 It is not the object of this research, however, that the proper understanding of the division between the incipient concepts of ownership and use (use) that St. Thomas Aquinas proposes in his classical work favors the analysis of his ideal of social function. Like this: "I answer that, two things are competent to man in respect of exterior things. One is the power to procure and dispense them, and in this regard it is lawful for man to possess property. Moreover this is necessary to human life for three reasons. First because every man is more careful to procure what is for himself alone than that which is common to many or to all: since each one would shirk the labor and leave to another that which concerns the community, as happens where 
1947 , p. 3345-3348).

However, it was in the nineteenth century that the ideals about social function found the necessary conditions for its theoretical development: supported by rationalist thinking and economic liberalism, the Industrial Revolution provoked profound social changes, privileging legal institutes built under the premise of unlimited ${ }^{14}$ freedom, embodied in bourgeois needs, advocated formal equality between contractors. To this end, it was suggested that, because they were endowed with reason, all people would be fully capable of, rationally, deliberating contractually. In this sense, Kant prescribes: "in man, law has ... the form of imperative, because, as a rational being, a pure will can be assumed in it" (KANT, 1959, 68). However, in practice, the belief in maximum contractual freedom has brought serious consequences to coexistence in society.

Initially, the working class - victimized by unimaginable ${ }^{15}$ abuses in the labor relationship, all under the aegis of free contractualism and abuse of property rights - reacted by advocating the destruction of the ruling class and the appropriation of the means of production; the social convulsion, then, provoked a search for the conciliation between the capitalist interests and those of the workers.

As an exponent of this conciliatory countermovement, there is the encyclical Rerum Novarum written by Pope Leo XIII in 1891. Although the papal text does not contain any mention of the social function proper and, in addition, point to socialism as a radical and harmful thought - including recommending to workers, subservience to employers - (LION XIII, 1891), the encyclical imputed to the capitalists, based on the dignity of the human person, the duty to improve the working conditions of the workers:

there is a great number of servants. Secondly, because human affairs are conducted in more orderly fashion if each man is charged with taking care of some particular thing himself, whereas there would be confusion if everyone had to look after any one thing indeterminately. Thirdly, because a more peaceful state is ensured to man if each one is contented with his own. Hence it is to be observed that quarrels arise more frequently where there is no division of the things possessed. The second thing that is competent to man with regard to external things is their use. In this respect man ought to possess external things, not as his own, but as common, so that, to wit, he is ready to communicate them to others in their need. Hence the Apostle says (1 Tim. 6:17, 18): "Charge the rich of this world . . to give easily, to communicate to others" etc." (AQUINO, 1947, p. 3347-3348).

14 According to Adam Smith at the time, freedom is the foundation of economic organization. Therefore, the market must be allowed to self-regulate, nationally and internationally, through its invisible hand (Smith, 1996, pp. 435-452).

15 As Huberman described in his book The History of Man's Wealth: "It is a new era in history that active and prosperous commerce is an index not of improving the situation of the working classes, but of their poverty and degradation" (GASKELL apud HUBERMAN, 1936, p.183) and working children aged 7 years and over (HUBERMAN, 1936, p.185). 
as for the rich and the bosses, should not treat the worker as a slave, but should respect the dignity of man. (...) It is shameful and inhuman to use men as instruments of profit, and to esteem them only in proportion to the strength of their arms. Christianity (...) also forbids employers to impose on their subordinates a job superior to their forces or in disharmony with their age or gender (LION XIII, 1891).

The content of the encyclical, it must be pointed out, was reaffirmed by Pope Pius XI through the encyclical Quadragesimo Anno which, in the text of Leo XIII, taught that the encyclical Rerum Novarum was "against the false theories of human freedom" and offered "to all mankind very sure rules for the good solution of the thorny problem of the human consortium, the so-called Social Question, precisely when it was most opportune and necessary." In particular, Pius XI stated that the preceding encyclical

although work (...) is not a mere commercial genre, but the human dignity of the worker must be recognized in it, and it can not be exchanged like any commodity, in fact today in the labor market supply and demand share the contractors in two opposing classes or camps, who fiercely oppose each other (PIO XI, 1931)

And, for the same purpose,he affirmed:

violates the right order, when capital enslaves the workers or the proletarian class with the purpose and condition that business and all economic progress are in their hands and revert to their advantage, despising the human dignity of the workers, the social function of economy and social justice itself and the common good (PIO XI, 1931).

Subsequently, Karl Renner broached the subject and advanced deeply in the conceptualization of the phenomenon. Under the strong influence of Marxist thought, he defined the social function as the reflection of the purpose of a legal institute in economics (RENNER 1981: 49). In addition, it should be pointed out that the Constitution of Weimar $^{16}$, of which he participated as a constituent, further elaborated

16 In the original, article 153 of the German Constitution of 1919 established: das Eigentum wird von der Verfassung gewährleistet. Sein Inhalt und seine Schranken ergeben sich aus 
this definition and provided that property - guaranteed, defined and limited by the constitution - obliges everyone and that its use must constitute a service for the common good (GERMANY, 1919).

This means that it is possible to distinguish the social function of property in two senses: the first as a purpose (or a role) indicative that every legal institute corresponds to an economic image and, te second, that the exercise of a right does not is dissociated from existing in society and, for this reason, more than compensating socially for the exercise of property, a social service must be provided as the right is exercised.

From all that is pointed out, it is not difficult to verify that the conceptual evolution of the social function took place from the property right. In this respect, the indiscriminate use of property has proved to be so damaging, historically, that its exercise had to be mitigated in the name of sociality so essential to human existence.

It was from the consolidation of the institute of the social function of the property that the social function of the contract was constructed as a limitation to the contractual freedom and, in addition, as a tool of socialization of the advantages or compensation of the damages deriving from the effects of contracting. This aspect is very relevant to this research, because the externalities of international investment agreements are subject to all nationals of the host State.

In this section, the foreign investor will only find legal certainty when they observe - in the construction of the investment agreement the one that is not considered more efficient cause of the right, but rather a final reason: Citizenship (CLAUDIA, 2014, 214 ). By unprotecting people from the host State, one is deprotecting the invested capital itself, after all, contrary to Classical International Law, which is based on the supposed axiological neutrality from a very liberal position, at the present time, human rights, although not consolidated, are fundamental to the stabilization of social expectations and, intrinsically, to the execution of international investment agreements (SILVA, 2016, p. 116).

It has been demonstrated that the social function is conditio sine qua non for the effective realization of legal security in the international investment business, since it is the host State, through its civil society, that will guarantee the fulfillment of the contracts, define the social

den Gesetzen. Eine Enteignung kann nur zum Wohle der Allgemeinheit und auf gesetzlicher Grundlage vorgenommen werden. Sie erfolgt gegen angemessene Entschädigung soweit nicht ein Reichsgesetz etwas anderes bestimmt. Wegen der Höhe der Entschädigung ist im Streitfalle der Rechtsweg bei den ordentlichen Gerichten offen zu halten, soweit Reichsgesetze nichts anderes bestimmen. Enteignung durch das Reich gegenüber Ländern, Gemeinden und gemeinnützigen Verbänden kann nur gegen Entschädigung erfolgen. Eigentum verpflichtet. Sein Gebrauch soll zugleich Dienst sein für das Gemeine Beste (GERMANY, 1919). 
division of labor and will provide the necessary predictability to the economic agents (LEISTER, 2011, 279), it remains to determine the effects of the social function on the rights of Citizenship.

\section{THE EFFECTS OF THE SOCIAL FUNCTION OF THE INTERNATIONAL INVESTMENT CONTRACT ON CITIZENSHIP RIGHTS}

The new economy that has been conforming since the end of the 20th century is, in fact, global and networked; after all, the circulation of capital is organized on a global scale and through a network of connections between economic agents (CASTELLS, 2000, p. In this scenario, it is essential to understand the effects of the foreign investment agreement on Citizenship. However, not from the classic effects, but those that are expressed by the social function of contracts. This is because the States, with intense globalization, have given part of their power to the market, which has in fact influenced the lives and behavior of people today (JAYME, 2005, p. 4).

In short, the quest is precisely to understand the intimate relationship between foreign investment - a component of the financial flow of the international market - and the life of the people in the national states, since it should not be forgotten that, regardless of the limits brought by international situation that is contemporary with the decision-making power of States (especially developing countries), it is the national governments that, after all, elect and implement measures that will determine the lives of their inhabitants. It is the responsibility of States : "no sólo las políticas sino también la elaboración de las normas estatales (...), la incorporación o no a determinadas convenciones internacionales (...) y la participación o no en procesos de integración" (ARROYO, 2005, p. 94) and, as stated by Arroyo, none of these state activities, nor the construction and execution of investment contracts, are or may be neutral; "cómo se orienten dependen en gran medida los efectos concretos que los fenómenos que trae aparejados la globalización están teniendo y van a tener en el futuro sobre los Estados" (ARROYO, 2005, p. 94).

In fulfilling its social function, the foreign investment agreement functions as a constraint on the dominance of international economic forces; consequently, it serves as a containment of the effects contrary to Citizenship that may arise from it. However, there is no naivety in this proposition: the financial market does not yield to the legal regulation of the sociality of the investment agreement by grace, but rather with a view to achieving its own interests. As is broadly stated in this article, foreign investment can only enjoy effective legal security when entering 
a national state if it is attentive to the interests of the Citizenship, in order to ward off the social upheaval capable of destabilizing all the protection to the economic effects of the investment made. The legal security conferred by the rule of law on foreign investment can only be achievable if justice and social welfare are observed; outside of this rule, the investment risk is unpredictable. And, undoubtedly, without predictability there is no transnational financial flow - which exposes the market to economic crises such as $2008^{17}$, for example.

Not least, through International Investment Law, minimum standards have been built, based on principles governing international agreements, under the requirement of clauses and conditions that observe the contractual good faith and the compatibility of the contracts with the constitutional order (DOLZER, Rudolf and Schreuer, Christoph, 2008, pp. 11-17) - in addition to attention to national legislation in general and customs. All this is to exclude the possibility of expropriatory measures, which are known to be adopted by the host State (Schrijver, 1995, pp. 108-111) in some situations.

From the awareness that law has apotential for socialemancipation directly related to "cosmopolitan movements, organizations and groups that use the law to take their struggles forward" (SANTOS, 2003, p. 71), the externality of the social effects of the foreign investment contract proves to be a relevant opportunity to struggle for the consolidation of citizens' rights as a resistance to the current economic horror (Forrester, 1997: 5-14) that has made the world a suitable place for economic, but little receptive to human existence worthy.

Therefore, what challenges Citizenship today is the exuberant and irrational domain of capitalism; there is an urgent need to relocate humanity in the global decision-making center, with references beyond consumerism and economics (BEDIN, 2009, pp. 173-174) - which will only be possible with the citizen's appropriation of the fracture spaces of the globalized financial market, as is the case of investment contracts that demand attention to sociality.

Undoubtedly, at the present time, human rights are part of international jus cogens, being hierarchically superior norms in the international legal order (RAMOS, 2009, p. 205), neglecting citizenship rights in the construction of foreign investment contracts is an impediment to the effective realization of the desired economic objective. Therefore, considering the system in which it is inserted, protecting human rights means facilitating the realization of the whole cycle underlying the foreign investment agreement, since without adequate protection of human rights in the realization of foreign

17 It is a profound global economic crisis, with an epicenter in the United States, whose peak occurred in 2008, causing negative growth rates and a prolonged deceleration of the global economy. Known as the subprime crisis. 
investment, there is no possibility of "ensuring the rule of law and the security of investments "(RAMOS, 2009, p.220).

Finally, in postmodernity ${ }^{18}$, human dignity integrates and informs international law (CASELLA, 2009: 249), proving to be a true paradigm of regulation and implementation of contracts, essential to the stability of international investments.

\section{CITIZEN CONTROL OVER THE INTERNATIONAL INVESTMENT AGREEMENT AS THE ACHIEVEMENT OF HUMAN RIGHTS WITH AN EMPHASIS ON THE RIGHT TO DEVELOPMENT}

In short, in the new universal society the financial flow goes beyond geographical, historical and cultural borders, multiplying their forms of articulation and contradiction, impacting daily life and social institutions (ROSADO, 2016, p. 351). In this scenario, citizen control of the international investment agreement is an opportunity that can not be ignored for the realization of social justice by guaranteeing that people access effective development; not only economic development, but to that which is reverted to a broad social benefit and to the construction of legitimate and democratic governments capable of ensuring that all the transnational financial flow, when entering the host State, is destined to the construction of social justice. It is, thus, the alignment of the investment contract, under citizen control, with the transformation that International Law itself in contact with International Human Rights Law has been promoting for the construction of a new global economic order based on cooperation, aiming at the development (FERREIRA, 2011, p. 51-52).

Although foreign investment is an indisputable source of growth promotion, especially for developing economies, only citizen control over investment agreements can prevent misallocation of resources that would, on the contrary, progressively increase the foreign capital, compromising the possibilities of "integral development, socially and culturally determined, supported in the legal guarantee of the effectiveness of the right to life and the dignity of the human person" (FERREIRA, 2011, p. 114-115).

In an inverse perspective, the implementation of human rights is fully reconcilable with foreign investment (ALMEIDA, 2014, p.609); and more than that, is an insurmountable condition for safe inversion. The premise that maximizing profit as the main draw for

18 According to Erik James, postmodernity is strongly inspired by plurality, communication, speed, fluency, narration, return to the feelings and internationality of private relations (JAYME, 1995, pp. 246-247). 
foreign investors is not at all mistaken - which would logically prevent the achievement of the human rights of the courts. The defect in this assertion is, however, in disregarding the social function of investment as an insurmountable condition for the promotion, regulation and protection of foreign investment.

Recent studies, including from the World Bank, point to the reciprocal benefits to citizenship and to the foreign investor when the investment is made with respect to citizenship rights: while the latter is protected against expropriation and observes a profitable return on capital employed, the citizens enjoy, for example, the reduction of infant mortality rates, the increase in the level of education of women and a high rate of success in completing infrastructure projects (ALMEIDA, 2014, p. 612).

Organized civil society, not only locally, but above all, through a system of global governance, should be vigilant to foreign investment contracts that should not be built under little or no transparency. An example of an opportunity for citizen control of foreign investment contracts is the advancement of UN member states in legal regulation with a view to ensuring transparency ${ }^{19}$ and public access to international investment arbitrations, including imposing their mandatory arbitration procedures under the UNCITRAL rule and, subsequently, by editing the Mauritian Convention on Transparency ${ }^{20}$, granting, certainly, greater legitimacy to arbitration decisions and security to litigants, fomenting ${ }^{21}$ the international investment market. At the same time, Citizenship benefits from being able to control ${ }^{22}$ arbitration procedures whose

19 Working Group II defined at its forty-eighth session that regulating transparency is "to improve the rules of publicity for actions, public access to documents and hearings, and the amicus curiae intervention", while ensuring that arbitral tribunals "protect all information that is truly confidential, with the presumption of free and public access to the actions ". And, according to the UNCITRAL Transparency Rule, confidential information is confidential business information; information restricted by treaty; protected information by internal legal order; information that impedes law enforcement and essential safety information.

20 This is the United Nations Convention on Transparency in Arbitrators between Investors and States within the Framework of a Treaty which seeks to extend the practical application of the United Nations transparency rule and is available for signature since 2015 . It will enter into force after the deposit of five Member States. Although signed by seventeen countries, only Maurício made the deposit, so far.

21 One of the consequences of the implementation of transparent practices in arbitration proceedings is the emergence of a case law bank that facilitates, expedites and guarantees well-informed and therefore safer and more effective decisions (ARROYO, 2016, pp. 244-271). 22 The UNCITRAL transparency rule empowers powerful civil society control tools. They are: the disclosure of all the constituent elements of the arbitration procedure, including documents produced by the parties or by the court; the holding of public hearings, as well as the availability of the transcription of the same; the availability of expert, documentary and witness evidence (at the request of any person or by court order); and the possibility of intervention by interested 
decisions may threaten to harm the citizens of the host State of foreign investment.

This is the effective opportunity to combat the concentration of world wealth and the aggravation of internal social inequalities, strengthening the democratic control by international multilateral institutions of the processes of transnationalization and financialization of the economy. Turning human rights into a global agenda reinforces the diversity and plurality so necessary to human development.

Foreign investors and receiving states can not, without voluminous damage, neglect protection of human beings - particularly amid the contradictions of the globalized financial market. As Cançado Trindade observed, "never, as in our day, has been so strongly advocated for an integral vision of human rights, to permeate all areas of human activity" (TRINDADE, 2003: 428). As exhaustively pointed out in this paper, the viability of peace building, human development and the maintenance and expansion of the global market is intrinsically linked to the protection of people across the globe.

\section{FINAL CONSIDERATIONS}

The complex network of connections - due to globalization in the contemporary world, which does not admit simplified solutions to the contradictions inherent to the main productive forces - profoundly affected the juridical relations coming especially from International Investment Law. In this scenario, it is affirmed in this work, that the search of the international financial market for legal security passes, inexorably, by the respect to the rights of the human people.

In the complex game of interests between civil society and capital, which nowadays surpass all geographical and cultural barriers, the potential of social emancipation of Law is revealed, creating an opportunity to fight for Citizenship. After all, the life of the people, around the globe, will not be transformed by contempt to the complex current social and economic reality; on the contrary, assuming and understanding the political, economic and productive dimensions is the most effective way of intervening to modify human existence.

If, in fact, law is always built in the interests of the socially powerful (LEISTER, 2011, 276), those who hold economic and politic control can not neglect the protection offered by the Law itself, and in moments of fracture - proper to the capitalist contradiction - expose to the Citizenship a true ring in which one can fight for the advance of the protective regulation of the real interests of the citizens. That is why, in this work, it is emphasized that emancipation by law is not a

parties, including the amicus curiae. 
gratuitous offer, but a forced assignment of those who control the law, in order to eliminate the ruin of the legal system and the consequent social collapse so feared.

The proposal to control civil society over foreign investments is not understood in a decontextualized way and seeks, ultimately, to protect people in receiving states against the barbarities of a world subject to the horrors of the global economy built on exploitation and accumulation.

Finally, the ideal of citizen control over contracts of foreign investment is built on two basic premises, which can not be forgotten: on the one hand, everyday life, under penalty of sudden perishing of the people who endure the greatest vilification, can not wait by the radical transformation of the productive system in force; human people need protection today and now. On the other hand must be acknowledged that the whole life of the law is a struggle (IHERING, 2009, p.23) and that no citizen achievement is definitively guaranteed, and the constant attention and vigilance of civil society is indispensable - not only for but especially to ensure that human guarantees are respected and social setbacks are removed. After all, "those who have much never forget to defend their interests" (PIKETTY, 2014, 561) and ignoring the possibility of law as a trench of contention to the lucrative drive of capital, brings no benefit to the poor.

\section{REFERENCES}

ALEMANHA. Die Verfassung des Deutschen Reichs, de 11 de Agosto de 1919. Reichsgesetzblatt, Schwarzburg, 11 ago. 1919. Disponível em: $\quad<$ https://www.jura.uni-wuerzburg.de/fileadmin/02160100/ Elektronische_Texte/Verfassungstexte/Die_Weimarer Reichsverfassung. $\overline{p d f}>$. Acesso em: 9 jun. 2017.

ALMEIDA, Bruno Rodrigues de. Investimentos estrangeiros diretos, direitos humanos e a ordem pública transnacional. In: RIBEIRO, Marilda Rosado de Sá. (Org.). Direito Internacional dos Investimentos. Rio de Janeiro: Renovar, 2014.

AQUINO, São Tomás de. Summa Theologica. Cincinnati: RCL Benziger, 1947.

ARAUJO, Nadia de. Contratos internacionais: autonomia da vontade, Mercosul e convenções internacionais. 2. ed. Rio de Janeiro: Renovar, 2000.

ARNAUD, André-Jean. Governar sem fronteiras. Rio de Janeiro: Lumen Juris, 2007.

ARROYO, Diego P. Fernández. El Derecho Internacional Privado en el 
Inicio del Siglo XXI. In: MARQUES, Claudia Lima; ARAUJO, Nadia de (Org.). O novo direito internacional: estudos em homenagem a Erik Jayme. Rio de Janeiro: Renovar, 2005.

Transparencia en el arbitraje de inversiones. In: TANZI, A. et al (Org.). International Investment Law in Latin America: Problems and Prospects. Boston: Nijhoff, Leiden, 2016. p. 244-271.

BAPTISTA, Patrícia Ferreira; RIBEIRO, Leonardo Coelho. Direito Administrativo global: uma nova ótica para a regulação financeira de investimentos. In: RIBEIRO, Marilda Rosado de Sá. (Org.). Direito Internacional dos Investimentos. Rio de Janeiro: Renovar, 2014.

BEDIN, Gilmar Antonio. A sociedade atual e seus três grandes desafios. In: CASELLA, Paulo Borba; RAMOS, André de Carvalho (Org.). Direito Internacional: Homenagem a Adherbal Meira Mattos. São Paulo: Quartier Latin, 2009.

CASELLA, Paulo Borba. Direito internacional e dignidade humana. In: CASELLA, Paulo Borba; RAMOS, André de Carvalho (Org.). Direito Internacional: Homenagem a Adherbal Meira Mattos. São Paulo: Quartier Latin, 2009.

CASTELLS, Manuel. A sociedade em rede. Volume 1.8 ed. São Paulo: Paz e Terra, 2000. Traduzido por Roneide Venancio Majer.

CASTRO, Emília Lana de Freitas. Contratos de Investimentos. In: RIBEIRO, Marilda Rosado de Sá. (Org.). Direito Internacional dos Investimentos. Rio de Janeiro: Renovar, 2014.

CNUDMI. Regramento, de 16 de dezembro de 2013. Reglamento de la CNUDMI sobre la Transparencia en los Arbitrajes entre Inversionistas y Estados en el Marco de un Tratado.

COSTA, José Augusto Fontoura. Proteção e promoção do investimento estrangeiro no Mercosul - uma ferramenta para a implementação de um bom clima de investimentos? Revista Brasileira de Política Internacional, Rio de Janeiro, n.49, p.60-77, 2006.

STRENGER, Irineu. Contratos internacionais do comércio. São Paulo: LTr, 1998.

Proteção internacional do investimento estrangeiro no Mercosul. Florianópolis: GEDAI, 2012. DOLZER, Rudolf; SCHREUER, Christoph. Principles of International Investment Law. Nova Iorque: Oxford University Press, 2008.

FERREIRA, Lier Pires. Direito internacional, petróleo e desenvolvimento. São Paulo: Saraiva, 2011. 
FORRESTER, Viviane. El horror económico. Buenos Aires: Fondo de Cultura Económica, 1997.

GEHLEN, Gabriel Menna Barreto Von. O chamado direito civil constitucional. In: COSTA, Judith Martins. (Org.). A reconstrução do direito privado. São Paulo: Revista dos Tribunais, 2004.

Grupo de Trabajo Sobre Arbitraje y Conciliación. Informe del Grupo de Trabajo sobre Arbitraje y Conciliación acerca de la labor de su $48^{\circ}$ período de sesiones (Nueva York, 4 a 8 de febrero de 2008). Nova Iorque: Asamblea General de Las Naciones Unidas, 2008. 28 p.

IHERING, Rudolf von. A Luta pelo Direito. São Paulo: 2009. Tradução de João de Vasconcelos.

HUBERMAN, Leo. História da Riqueza do Homem. Nova Iorque: 1936. Tradução de Waltensir Dutra.

HURREL, Andrew. On Global Order: Power, Values, and the Constitution of International Society. Nova Iorque: Oxford University Press, 2007.

JAYME, Erik. Identité culturelle et intégration : le droit international privé postmoderne. In: Collected Courses of the Hague Academy of International Law. Boston: Brill Nijhoff, 1995.

. O Direito Internacional Privado do novo milênio: a proteção da pessoa humana face à globalização. In: MARQUES, Claudia Lima; ARAUJO, Nadia de (Org.). O novo direito internacional: estudos em homenagem a Erik Jayme. Rio de Janeiro: Renovar, 2005. Traduzido por Claudia Lima Marques.

JUNIOR, Ely Caetano Xavier. As (in)definições de investimento estrangeiro. In: RIBEIRO, Marilda Rosado de Sá. (Org.). Direito Internacional dos Investimentos. Rio de Janeiro: Renovar, 2014.

JÚNIOR, Lauro Gama. Contratos internacionais à luz dos princípios UNIDROIT 2004: soft law, arbitragem e jurisdição. Rio de Janeiro: Renovar, 2006.

KANT, Immanuel. Crítica da Razão Prática. São Paulo: Brasil Editora, 1959. Tradução de Afonso Bertagnoli.

LEÃO XIII, Papa. Carta encíclica Rerum Novarum sobre a condição dos operários. Roma: 1891. Disponível em: <https://w2.vatican.va/ content/leo-xiii/pt/encyclicals/documents/hf_1-xiii_enc_15051891 rerum-novarum.html $>$. Acesso em: 9 jun. 2017.

LEISTER, Margareth Anne. Estado de direito e comércio internacional. In: BASSO, Maristela; PRADO, Mauricio Almeida; ZAITZ, Daniela. (Org.). Direito do Comércio Internacional: pragmática, diversidade 
e inovação. Curitiba: Juruá, 2011.

MARQUES, Claudia Lima. Contratos no Código de Defesa do Consumidor: o novo regime das relações contratuais. 7 ed. São Paulo: Revista dos Tribunais, 2014.

PIKETTY, Thomas. O Capital no século XXI. Rio de Janeiro: 2014. Tradução de Monica Baumgarten de Bolle.

PIO XI, Papa. Carta encíclica Quadragesimo Anno sobre a restauração e aperfeiçoamento da ordem social em conformidade com a lei evangélica no XL aniversário da encíclica de Leão XIII Rerum Novarum. Roma: 1931. Disponível em: <https://w2.vatican. $\mathrm{va} /$ content/piusxi/pt/encyclicals/documents/hf_pxi_enc_19310515_ quadragesimo-anno.html $>$. Acesso em: 9 jun. $20 \overline{17}$.

RAMOS, André de Carvalho. Os modelos de interação entre direitos humanos e os processos de integração econômica. In: CASELLA, Paulo Borba; RAMOS, André de Carvalho (Org.). Direito Internacional: Homenagem a Adherbal Meira Mattos. São Paulo: Quartier Latin, 2009.

RENNER, Karl. Gli istituti del diritto privato e la loro funzione sociale. Bologna, 1981.

RIBEIRO, Marilda Rosado de Sá. Expropriação: revisitando o tema no contexto dos estudos sobre investimentos estrangeiros. In: RIBEIRO, Marilda Rosado de Sá. (Org.). Direito Internacional dos Investimentos. Rio de Janeiro: Renovar, 2014.

RODRÍGUEZ, José Antonio Moreno. Contratos. 2 ed. Assunção: CEDEP, 2013.

ROSADO, Marilda. Novos rumos do Direito Internacional Privado. In: ARROYO, Diego P. Fernandez; RODRÍGUEZ, José Antonio Moreno. (Org.). Contratos internacionales. Buenos Aires: ASADIP, 2016.

SANTOS, Boaventura de Sousa. A Globalização e as Ciências Sociais. São Paulo: Cortez, 2002.

Poderá o direito ser emancipatório?

Revista Crítica de Ciências Sociais, Coimbra, v. 1, n. 65, mai. 2003.

SCHRIJVER, Nicolaas Jan. Sovereignty over natural resources: balancing rights and duties in an interdependent world. Groninga: Universidade de Groninga, 1995.

SILVA, Elaini Cristina Gonzaga da. Direito internacional em expansão: encruzilhada entre comércio internacional, direitos humanos e meio ambiente. São Paulo: Saraiva, 2016.

SMITH, Adam. A Riqueza das Nações: investigação sobre sua 
natureza e suas coisas. Volume 1. São Paulo: Círculo do Livro, 1996. Traduzido por Luiz João Baraúna.

STRENGER, Irineu. Contratos Internacionais do Comércio. 3 ed. São Paulo: LTr, 1998.

TRINDADE, Antônio Augusto Cançado. Tratado de Direito Internacional dos Direitos Humanos. Porto Alegre: Sergio Antonio Fabris Editor, 2003.

TRINDADE, Otávio A. D. Cançado. O Mercosul no Direito brasileiro: incorporação de normas e segurança jurídica. Belo Horizonte: Del Rey, 2007.

VASCONCELOS, Raphael Carvalho de. Teoria do Estado e a Unidade do Direito Internacional. Belo Horizonte: Arraes, 2016.

VEDOVATO, Luís Renato; VEDOVATO, Tatiana Giovanelli; SPERANDIO, Ana Maria Girotti. O papel do Direito Internacional na legislação interna sobre o controle do tabaco. Revista de Direito Sanitário. São Paulo, n. 3, v. 13, p. 150-175, nov./fev. 2013.

VICENTE, Dário Moura. La autonomía privada y sus distintos significados a la luz del derecho comparado. In: ARROYO, Diego P. Fernandez; RODRÍGUEZ, José Antonio Moreno. (Org.). Contratos internacionales. Buenos Aires: ASADIP, 2016. 